\title{
Pursuing International Opportunities in a Digitally Enabled World
}

\author{
Di Song and Aiqi Wu
}

\begin{abstract}
Digitalization has tremendously challenged how international opportunities are created and captured. Inspired by researches in the field of both entrepreneurship and international business, this study provides a comprehensive framework toward the impact of digital technologies (DTs) on opportunity pursuit in foreign markets. We identify two perspectives of DTs, i.e., DTs as 'driving force' and DTs as 'disrupting force,' which characterize DTs as a catalyst of experiential knowledge acquisition, and as a factor altering the relative significance of experiential knowledge to opportunity pursuit, respectively. By bridging these two perspectives with the notion of market-specific knowledge and general knowledge within internationalization process theory, some arguments with regard to what specific influences DTs play on international opportunity pursuit are further introduced. We hope this study can potentially offer some nuances to both practitioners as well as the research in the interaction of digitalization and international opportunity.
\end{abstract}

\section{The Relevance of Digitalization to International Opportunity Pursuit}

It is undeniable that an increasing number of firms pursue international opportunities in an era of digitalization. In China, for instance, some leading Internet companies such as Alibaba and Tencent make a profit in the global market. Meanwhile, thousands of manufacturing firms are also dependent upon emerging

D. Song $(\bowtie) \cdot$ A. Wu

Zhejiang University, Hangzhou, China

e-mail: songdi@zju.edu.cn

(C) The Author(s) 2021

M. Soltanifar et al. (eds.), Digital Entrepreneurship, Future of Business and Finance,

https://doi.org/10.1007/978-3-030-53914-6_13 
technologies to reach their customers outside the domestic country. Indeed, digitalization has challenged the traditional way of entrepreneurial opportunity pursuit. With the help of new technologies, firms can better access to online communities, incubators, and accelerators (Glavas et al. 2019), connect with foreign experts (Sigfusson and Chetty 2013), involve in international activities without abundant investments (Coviello et al. 2017), and so forth. In essence, thanks to this trend, international opportunities are becoming more available for the firm than the past.

However, as international business scholars have repeatedly underscored, practitioners should consider the unique characteristics of foreign markets while conducting cross-border activities. Despite profound effects made by emerging technologies, some differences between the home country and host countries still exist. Cultural distance between each economy cannot be ignored, and protectionism in trade and finance has been strong in recent years. So, how international opportunities could be created and captured in a digitally enabled world? In this article, we aim at offering a conceptual framework by drawing on the research in entrepreneurship, international business, and digitalization to understand this important issue.

\section{Background}

In order to systematically examine the impact of digitalization on international opportunity pursuit, we first review some associated arguments in literature of both entrepreneurship and international business. ${ }^{1}$

Opportunity is a central concept for international entrepreneurship research in particular (Reuber et al. 2018; Oviatt and McDougall 2005) and for entrepreneurship research in general (Shane and Venkataraman 2000; Kirzner 1997). Following Eckhardt and Shane (2003: 336), entrepreneurial opportunities can be defined as 'situations in which new goods, services, raw materials, markets and organizing methods can be introduced through the formation of new means, ends, or means-ends relationships.' As such, cross-border opportunities are assumed to objectively exist, and necessary knowledge is needed to pursue them (Foss et al. 2013; Shane 2000). Though indispensable role of opportunities has been underscored, some scholars were skeptical about studying entrepreneurial activities exclusively based on the notion of opportunity (e.g., Davidsson 2015; Alvarez and Barney 2014). Empirical researches indicated that entrepreneurial opportunities cannot be automatically translated into superior performance (Wu et al. 2019; Hmieleski and Baron 2008). To interpret the results, we should be aware that Shane and Venkataraman (2000) have already insightfully proposed that there are

\footnotetext{
${ }^{1}$ We argue that to examine these two streams of literature is reasonable. It should be noted that, while the concept of 'opportunity' is central for international entrepreneurship (Oviatt and McDougall 2005; Mainela et al. 2014), international entrepreneurship was regarded to be the intersection of IB and entrepreneurship (McDougall and Oviatt 2000). Further, the analysis of 'opportunity' is a common theme for these two research areas (Reuber et al. 2018).
} 
opportunity costs to take advantage of an entrepreneurial opportunity. Opportunities are always intertwined with the environment where pursued (Young et al. 2018). Therefore, it is of vital importance to jointly consider opportunities and the context where opportunities are created and captured.

To pursue opportunities in the global context, firms are supposed to decide on where, when, and how to create and capture them (Knight and Liesch 2016). To answer these important but related questions, internationalization process (IP) theory (Johanson and Vahlne 1977) provides us a useful guideline on which the current analysis could potentially rely. Inspired by a series of case studies primarily conducted by researchers of Uppsala University in 1970s, IP theory has become one of the prominent perspectives in mainstream international business literature. ${ }^{2}$ As IP theory maintains, firms expand abroad in an incremental way because they should accumulate enough experiential knowledge so as to mitigate perceived risks that prevents them from effectively creating and capturing opportunities in foreign markets (Johanson and Vahlne 1977).

In specific, Eriksson et al. (1997) divided international business knowledge into three conceptually distinctive forms, i.e., foreign business knowledge, foreign institutional knowledge, and internationalization knowledge. The first two types of experiential knowledge, highlighting market-related knowledge (i.e., knowledge about customers, suppliers, and competitors) and non-market-related knowledge (i.e., knowledge about rules, norms, government policy and regulations), respectively, were termed as market-specific, whereas internationalization knowledge, termed as general knowledge, is associated with organizational structures for international operations, and thus characterized as those universal and versatile across different markets. The explanation for different types of knowledge is summarized in Table 1. The accumulation of either type of knowledge can be potentially beneficial for lowering perceived risks in foreign markets (Fletcher and Harris 2012; Hilmersson and Jansson 2012; Zhou 2007; Blomstermo et al. 2004), and thus encourage the firm to create and capture opportunities in the market.

Although IP theory was originally developed to study the internationalization pathway of well-established firms, subsequent researches have observed IP theory is also applied to new ventures (Lopez et al. 2009; Hashai 2011). In theory, new ventures are faced with great difficulties to pursue international opportunities, as they have relatively little experiential knowledge and should invest existing resources to create routines adapting to businesses in foreign markets (Sapienza et al. 2006). As such, their activities are largely constrained by insufficient knowledge introduced by IP theory as well. Therefore, it is theoretically and practically meaningful to investigate how cross-border opportunities can be pursued in a digitally enabled world by focusing on elements of IP theory.

\footnotetext{
${ }^{2}$ Some evidence can support this argument. Johanson and Vahlne (1977), as the founding article for IP theory, have been on the list of 'Most cited articles' of Journal of International Business Studies (JIBS) (https://www.palgrave.com/gp/journal/41267/volumes-issues/most-cited-articles). As of Dec 13, 2019, this article has been cited for 14,099 times based on Google Scholar. Furthermore, Johanson and Vahlne (2009), as a revised version of the IP theory, have been awarded JIBS decade award in 2019.
} 
Table 1 A brief description of each dimension of experiential knowledge

\begin{tabular}{l|l|l}
\hline & Knowledge type & Definition \\
\hline $\begin{array}{l}\text { Market-specific } \\
\text { knowledge }\end{array}$ & $\begin{array}{l}\text { Foreign business } \\
\text { knowledge }\end{array}$ & $\begin{array}{l}\text { Experiential knowledge about clients, the market, } \\
\text { and competitors }\end{array}$ \\
\cline { 2 - 3 } $\begin{array}{l}\text { Foreign institutional } \\
\text { knowledge }\end{array}$ & $\begin{array}{l}\text { Experiential knowledge about government, } \\
\text { institutional framework, rules, norms, and values }\end{array}$ \\
\hline $\begin{array}{l}\text { General } \\
\text { knowledge }\end{array}$ & $\begin{array}{l}\text { Internationalization } \\
\text { knowledge }\end{array}$ & $\begin{array}{l}\text { Experiential knowledge about the firm's capability } \\
\text { and resources to engage in international operation }\end{array}$ \\
\hline
\end{tabular}

Source Adapted from Eriksson et al. (1997)

\section{Conceptual Model: The Influence of Digital Technologies to International Opportunity Pursuit}

According to Tilson et al. (2010: 749), digitalization refers to 'a sociotechnical process of applying digitizing techniques to broader social and institutional contexts that render digital technologies infrastructural.' Building on this notion, the understanding of international opportunity pursuit in a digitally enabled world can be enriched by an exploration of how digital technologies (DTs) impact on the way of pursuit previously characterized (Autio et al. 2018). The concept of DTs has been broadly defined, and in line with Nambisan (2017), DTs consist of many elements which could be classified into three groups, i.e., digital artifacts (components and functions of product or service), digital platform (architectures hosting complementary offerings), and digital infrastructure (broad digital tools and systems). These three groups of DTs are intertwined with each other and collectively influence entrepreneurial activities (Nambisan 2017).

As aforementioned arguments indicate, either market-specific knowledge or general knowledge is closely associated with international opportunity pursuit. To investigate the impact of DTs, we are now interested in how DTs affect the original relationship. We propose that DTs could be viewed as either one of the two roles, which were labeled as 'driving force' and 'disrupting force,' respectively. The explanation for these two roles is summarized in Table 2. When DTs are viewed as 'driving force,' it is assumed to be a facilitator for acquiring market-specific knowledge and general knowledge. DTs are positioned as the antecedents of knowledge acquisition. In this sense, DTs can be understood as a 'reformer.' By contrast, when DTs are viewed as 'disrupting force,' we regard DTs as the factor that alters the relative importance of experiential knowledge to international opportunity creation and capture. The effect of market-specific knowledge and general knowledge on opportunity pursuit is moderated by DTs. In this sense, DT can be paraphrased as a 'revolutionary.'

To better facilitate the interpretation of two distinctive roles of DTs, we integrate DTs with the model based on IP theory, which is illustrated in Fig. 1. It is shown that DTs can be either viewed as the antecedent of the experiential knowledge or as the contingent effect of the knowledge-opportunity relationship.

Below, we discuss two perspectives of DTs in detail. 
Table 2 Two perspectives of DTs

\begin{tabular}{l|l|l}
\hline & DTs as 'driving force' & DTs as 'disrupting force' \\
\hline Assumption & $\begin{array}{l}\text { DTs facilitating experiential } \\
\text { knowledge acquisition }\end{array}$ & $\begin{array}{l}\text { DTs changing the relative importance of } \\
\text { experiential knowledge }\end{array}$ \\
\hline Role & $\begin{array}{l}\text { The explanatory variable for } \\
\text { knowledge acquisition }\end{array}$ & $\begin{array}{l}\text { The moderating effect for the influence of } \\
\text { knowledge }\end{array}$ \\
\hline Metaphor & DTs seen as a 'reformer' & DT seen as a 'revolutionary' \\
\hline
\end{tabular}

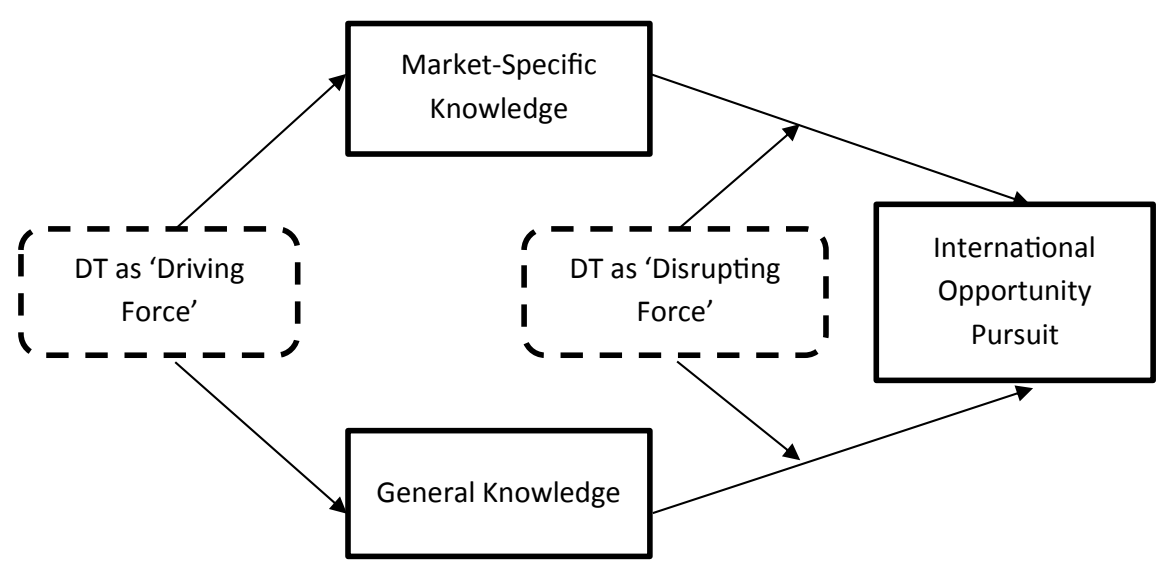

Fig. 1 Influence of Digital technologies (DTs) on international opportunity pursuit

\subsection{DTs as 'Driving Force'}

The perspective that views DTs as 'disrupting force' underlines the way of experiential knowledge accumulation is influenced by these emerging technologies (Coviello et al. 2017). According to this perspective, both market-specific knowledge and general knowledge could be increasingly accumulated with the help of technologies. Thus, DTs would be indirectly associated with international opportunity pursuit, and the relationship is mediated by experiential knowledge. We discuss how this can happen as follows.

\section{Market-specific knowledge}

Enhanced knowledge availability owing to DTs application can directly bring information about the potential market, allowing them to identify which markets are attractive for them (Coviello et al. 2017). Generally speaking, accelerated market-specific knowledge accumulation is gathering an increasing amount of knowledge about other players. By investigating a group of Indian IT firms, Paul and Gupta (2014) claimed psychic distance is largely reduced in recent years, as a consequence of learning from virtual community through online interactions. 
Similarly, Pergelova et al. (2019) found that DTs encourage the improvement of international marketing intelligence that would potentially enhance export propensity of SMEs.

In specific, information accessibility about customer's need can be brought by DTs (Autio 2017; Okazaki and Taylor 2013; Yamin and Sinkovics 2006). Many digitally enabled facilities, including e-mails (Prasad et al. 2001), customer databases (Yamin and Sinkovics 2006), and social networks (Alarcón-del-Amo et al. 2018), would encourage international business activities by offering valuable information about customers for the focal firm. In an empirical test concerning internationalization of online apps, Shaheer and $\mathrm{Li}$ (2020) observed that between-country distance still has an impact on foreign expansion of these digitalized product providers. However, barriers resulted from distances can be lowered by proactive online user-friendly strategies, including social sharing strategy and virtual community strategy, which encourage the firm to acquire necessary updated information about foreign customers.

Except for customers, experiential knowledge about collaborators and competitors in target market can also be accessed as a result of DTs (Mathews et al. 2016). Gregory et al. (2007) observed from their empirical results that exporters gain knowledge about local distribution channels by using the Internet, which would optimize communication and distribution for these exporters. Overall, a greater amount of information with regard to other players can encourage opportunity creation and capture in specific market by lowering perceived risks.

In particular, compared with established counterparts, we conjecture new venturing firms can benefit more from DTs which help overcome liability of newness (Gabrielsson and Gabrielsson 2011). As novices, new ventures usually deal with the situation where other players are overwhelmingly strangers (Stinchcombe 1965). Such risks would be mitigated through the application of DTs. Glavas et al. (2019) found owners of small firms can utilize digital platforms to collect information about potentially available customers, supporting the notion that DTs might be meaningful for new ventures in this sense.

Foreign market knowledge can not only be accumulated by firm-level business network, but also be derived from entrepreneur's social network through DTs. Especially, social networking platform has transformed the process of information transfer. For instance, by examining how international entrepreneurs accumulate foreign market knowledge on LinkedIn, Sigfusson and Chetty (2013) found some entrepreneurs directly look for reliable foreign partners who possibly provide confidential information.

Furthermore, foreign institutional knowledge, both informal and formal one, can also be acquired with the help of DTs. Knowledge about informal institutions, such as customary habits in a certain market, may be explored and thus fulfilled in a more sophisticated way with the help of DTs (Yamin and Sinkovics 2006; Prasad et al. 2001). The application of DTs allows the reduction of the cost associated with information search beyond the national border. In terms of formal institution, Glavas et al. (2019) found that a more nuanced understanding of regulatory 
institutions can be encouraged by participating digital platforms, which is achieved via multiple search engines and multimedia resources.

\section{General knowledge}

While market-specific knowledge acquisition process can be largely influenced by the application of DTs, it is also true for the acquisition of general knowledge. In particular, the application of DTs may potentially reshape the organizations. Building on a cultural perspective, Mathews et al. (2016) proposed that the emerging technology platforms force the firms to be exposed in a global context, which encourages decision-makers to be more adaptable to and more willing to learn and appreciate about other cultures. This leads to the firm to take a more international identity, and force the firm to know better about how to internationalize. In a similar vein, Autio (2017) underscored that DTs enable a more an adaptable organizational structure for foreign operations, by enhancing the flexibility of the structure to better orchestrate resources and try varied value propositions in foreign markets.

\section{Contingent factor: knowledge acquisition heterogeneity}

Although DTs would encourage the firm to accumulate knowledge, it should be highlighted that not all firms can equally benefit (Alarcón-del-Amo et al. 2018; Sigfusson and Chetty 2013; Moen et al. 2008). There are at least three reasons leading to this heterogeneity. Firstly, the amount of knowledge can be accumulated and can be dependent on for what purposes DTs are utilized. To illustrate this notion, it is observed that applying DTs for information search or relationship development can contribute to knowledge accumulation, while using DTs only for sales activity would not bring significantly more knowledge (Moen et al. 2008).

Secondly, knowledge acquisition is also influenced by firm's degree of commitment to technologies. Some past studies support this argument (Glavas et al. 2019; Sigfusson and Chetty 2013). For instance, Alarcón-del-Amo et al. (2018) investigated the role of social media application among export-oriented companies, concluding that only those with high commitment of social media can obtain sufficient market knowledge by communicating better with their customers. In a similar vein, Sigfusson and Chetty (2013) indicated knowledge accumulation could be more effective when proactive activities are taken in the cyberspace.

Thirdly, firm characteristics could also explain the source of this heterogeneity. For example, Moen et al. (2008) argued that firm age could be a significant contextual factor for foreign market acquisition enabled by DTs. To maintain the extant customer relationships, older exporters may be less motivated to use DTs as a way to accumulate new market knowledge. This position is consistent with an organizational learning argument in international entrepreneurship literature which highlights younger organizations are in general more flexible for knowledge acquisition than older ones (Autio et al. 2000; Sapienza et al. 2006). Furthermore, Glavas et al. (2019) observed the internationalization stage and pattern, including the phase of internationalization (i.e., pre, early, later) and the pace of internationalization (i.e., incremental, non-incremental), can also be influential for types of acquired knowledge. 


\subsection{DTs as 'Disrupting Force'}

Another perspective understands DTs as 'disrupting force,' which highlights that functions or affordances of DTs can reshape business activities (Autio et al. 2018; Nambisan 2017; Yoo et al. 2012). The internationalization pattern has fundamentally changed (Coviello et al. 2017; Alcácer et al. 2016; Autio 2017), and the relative significance of experiential knowledge with regard to international opportunity creation and capture is assumed altered, no matter experiential knowledge still plays a role or not. From this perspective, by changing the way of business activities are conducted in the international marketplace, these emerging technologies allow the pursuit of cross-border opportunities less constrained by the amount of knowledge firms possess as suggested by traditional IP theory. Sometimes, DTs also introduce new forms of knowledge and capabilities that firms require in order to pursue international opportunities.

\section{Market-specific knowledge}

With regard to market-specific knowledge, there are at least two reasons why it is not equally significant for opportunity pursuit in a digitally enabled world. In the first place, customers get involved in value creation with the help of DTs (e.g., Chandra and Coviello 2010; Amit and Han 2017). Chen et al. (2019) emphasized the relative importance of knowledge for market entry is decreased from the point view of network effects. For app developers, foreign market penetration is sometimes not purposeful since borderless user networks can help to channel to product information to consumers in other countries. Inspired by the research, we conjecture that international opportunity creation and capture is realized largely owing to demand-side network effects rather than purely supply-side knowledge accumulation.

In the second place, alternative governance approach is available enabled by DTs (Coviello et al. 2017; Alcácer et al. 2016). Different from 'prudent' within-firm administrative control documented in early IP theory literature (Johanson and Vahlne 1977), the prevalence of emerging technologies allows the firm to loosely separate each unit of the whole firm in different countries. As such, firms are able to conduct business abroad easily by cooperating with foreign contractors instead of controlling tangible assets. Therefore, enabled by DTs, ownership advantage is not only associated with the proprietary rights over certain resources, but also in connection with the ability to orchestrate resources across the globe (Alcácer et al. 2016). In an empirical investigation of international technology alliances, Lew et al. (2016) observed that fragmentation of product modular permits alliance with the internalization of partner's specialized knowledge, and the relationship between alliance partners is less susceptible to the cultural distance. It demonstrates that comparatively loose collaboration is likely among the international technology alliances setting. Overall, this suggests that with the help of DTs, even if not familiar with the specific market, the firm is also likely to international opportunities. 


\section{General knowledge}

Digitalization further revolutionizes international business by lowering the relative significance of general knowledge to international opportunity pursuit. Foremost, DTs enable internationalizing firms, especially exporting manufacturers, to sell their products through cross-border electronic commerce channels or platforms by simply clicking the mouse (Tolstoy et al. 2016). This has fundamentally changed the original international business manner since little foreign business knowledge is already adequate for some activities.

At the same time, some other kinds of general knowledge, however, are becoming increasingly indispensable for opportunity pursuit in the international marketplace. For example, Reuber and Fischer (2011) identified three types of online resources, i.e., online reputation, online technological capabilities, and online brand communities, can be instrumental for new venture internationalization. The general knowledge about how to encourage the firm to accumulate these online resources can buffer the risks of doing business abroad (Fischer and Reuber 2014), and facilitate opportunity pursuit. In sum, whereas some part of general knowledge highlighted by traditional IP theory would be less significant for internationalization, successful international opportunity creation and capture requires other additional knowledge.

\section{Examples from Practice}

\section{EXHIBIT 1: Selling ambers to China with the help of WeChat (DTs as 'driving force')}

It is undeniable that China is an attractive market for enterprises around the world. However, it has also been widely acknowledged that doing business in China would not be easy (Ahlstrom et al. 2000), as cultural distance is usually so pronounced and China's institutional development is not as fast as its economic development.

In order to accumulate sufficient knowledge to create and capture opportunities in China, many foreign firms rely on survey reports and business networks. Meanwhile, other entrepreneurs and managers realize that DTs can also play an essential role. For example, WeChat, as one of China's most frequently used social networking platform, has attracted an increasing number of users outside China. Released in 2011, WeChat penetrates into Chinese people's daily life thoroughly and has become a main channel for information exchange of works and social activities in China. It is reported that the number of monthly active users (MAU) has reached 1112 million during the first quarter of year 2019 (Tencent 2019).

Many Chinese tourists find it quite cost-efficient to buy ambers while visiting Poland. In line with the tradition, some Chinese ladies have a habit of wearing the amber necklace to show the elegance. For Polish sellers, accessing to Chinese market means a lot to their amber business. However, without sophisticated knowledge about the market, it seems to be a challenge for Polish businessmen to 
pursue profitable opportunities in the Far East. The idea of 'beauty' is historically and socially constructed, and the values are sharply different between the East Europe and China. Moreover, as small-sized independent business, Polish sellers have comparatively limited understanding with regard to China's markets and institutions.

To address these shortcomings, a group of amber sellers in Warsaw registered their accounts on WeChat platform after observing a wealth of Chinese clients sent pictures of ambers and sought for advice from their friends through WeChat while visiting the store. By adding WeChat friends with Chinese buyers, these Polish amber sellers repeatedly interact with their customers, delivering ambers through the international express transportation. Some of them even established the WeChat group which allows to introduce new products and simultaneously receive valuable feedbacks from Chinese customers. Because these WeChat groups are generally open for everyone, consumers on occasions invite their friends and relatives who are also interested in Polish amber to the group chat. Through the use of WeChat, amber sellers expand the market scope by accumulating knowledge about the potential customers, which partially overcome the liability of foreignness (Zaheer 1995). Furthermore, these Polish businessmen acquire first-handed knowledge about their customers and competitors in China, as well as significant information regarding values and habits through informal interactions, which allows them to design their products more popular among Chinese customers than before.

\section{EXHIBIT 2: Internationalization at home (DTs as 'disrupting force')}

China is one of the major exporters of world's production. Although a growing number of factories have been built in Africa and South Asia over the course of last decade, many companies on the planet still expect for the long-term procurement of a large number of commodities from China. 'Made in China' is perceived to be attractive if price and quality are jointly considered. To explore reliable partners, foreign businessmen used to come to some Chinese cities such as $\mathrm{Yiwu}^{3}$ and Guangzhou, in order to search for necessary information about the market and the institution. Managers and entrepreneurs in these cities are scarcely trained to speak foreign languages, and therefore, it spends foreign businessmen a lot of efforts to discuss and make the deal. Furthermore, institutional voids in many places of China also discourage foreign companies from collaborating with Chinese counterparts. As a consequence, even though a wide range of valuable opportunities could be possibly explored in China, many foreign companies are blind to them because of possessing insufficient knowledge about China.

In recent years, with the development of digitally enabled trading and payment platforms, there is an alternative approach to do business with suppliers in China. The exchange of commodities is realized through the cross-border e-commerce platforms such as AliExpress (www.aliexpress.com) and DHgate (www.dhgate. com). These digital platforms connect thousands of Chinese small businesses to the

\footnotetext{
${ }^{3}$ Yiwu, a county-level city situated in the center of Zhejiang Province of China, has been widely regarded as 'world's largest wholesale market for daily commodities.' Thousands of village and township enterprises that manufacture various kinds of daily commodities are established in Yiwu.
} 
customers worldwide, and registration on the platform is required for both sellers and buyers before transactions take place. The platform can be accessible for individuals anywhere in the world only if there is an Internet connection. Geographical distance is no longer a big deal.

In DHgate, for example, the platform owner provides the Web page with a number of language versions. Chinese suppliers are allowed to display their products online on a Chinese-language Web page, while foreign buyers could visit the Web site and choose what they expect to order on an English-language Web page. Furthermore, instead of requiring adequate knowledge about Chinese suppliers, foreign businessmen are able to make their decisions by browsing the reviews and the ratings from other buyers. Online payment system endorsed by the platform could also go against the potential opportunistic behaviors, which make the exchange process smooth.

These functions facilitate foreign companies with very limited experiential knowledge about China's institutions and markets to touch the profit opportunities in this market. It illustrates that, with little experiential knowledge, international opportunity creation and capture is also likely when DTs are properly applied.

\section{Discussion and Conclusion}

\subsection{Contribution}

By examining how international opportunities are created and captured in a digitally enabled world, the current study would have some implications for both theory and practice. In terms of theory, we provide some nuances to understand the intersection of digitalization and international opportunity pursuit by identifying what roles DTs play in firm internationalization. Drawing on insights from the research in entrepreneurship, IB, and digitalization, we develop a conceptual framework and classify the role of DTs into two distinctive perspectives, namely DTs as 'driving force' and DTs as 'disrupting force.' Whereas DTs as 'driving force' can be interpreted as a catalyst for acquisition of market-specific knowledge and general knowledge, DTs as 'disrupting force' maintain these emerging technologies alter the relative significance of experiential knowledge to international opportunity creation and capture by both lowering the importance for some and putting forward new requirements for the firm. While digitalization and its impact on international opportunity pursuit has been a hot topic (Eduardsen and Ivang 2016), the current study would guide the research in this stream by structuring the role of DTs.

In terms of practical implications, our analysis along with the introduction of the conceptual model might offer some insights for practitioners regarding how DTs have transformed the way that cross-border opportunities are pursued. Primarily, practitioners can learn from this study about the way the accumulation of knowledge conducive for successful opportunity pursuit is facilitated in a digitally 
enabled world. By demonstrating how firm's stock of both market-specific knowledge and general knowledge can be enriched by using DTs, practitioners are provided some guides with respect to the mitigation of risks associated with international activities.

Secondly, as highlighted by the perspective of DTs as 'disrupting force,' the significance of experiential knowledge may not be as important as how traditional IP theory predicts, because of DTs could disrupt the way how international opportunities are pursued. Thanks to these emerging technologies, new approaches to pursue opportunities are introduced, which allow experiential knowledge less indispensable, but requires some additional knowledge intertwined with the trend of digitalization. By doing this, we offer some insights for practitioners which help to think about their design of business models.

Thirdly, our study also encourages practitioners to scrutinize how to utilize DTs in their activities. Though firms are nowadays extensively exposed to DTs, not all firms can equally benefit from digitalization. In practice, only a portion of firms could successfully take advantage of these technologies and achieve a favorable outcome. Our study emphasizes a few factors that theoretically explain the heterogeneity of the amount of knowledge that firms can accumulate with the help of DTs, which offers some illustrations allowing practitioners to consider how DTs matter for their businesses.

\subsection{Future Research}

Though some insights are provided by this study, we should acknowledge that we have only done initial works and several avenues can be considered for future researches. Primarily, since we are not ambitious to cover all arguments in this article, some very important insights in the literature may be overlooked. Furthermore, as IP theory, a prevalent approach among international business research, was the basis for developing our conceptual model, readers should be aware that IP theory itself relies on strong assumptions of the firm and the entrepreneur. In general, entrepreneurs are assumed to be basically risk-aversive (Welch et al. 2016), and thus experiential knowledge becomes the cornerstone for international opportunity creation and capture. In this sense, firms largely prefer long-term profits and organic growth. Although some entrepreneurs are quite conservative in practice, other ones are not concern much with international business knowledge (Zahra 2005) and hope to pursue opportunities across the globe as rapidly as possible. Thus, while our conceptual model may be useful, the heterogeneity of both the firm and the entrepreneur is ought to be taken into considerations.

Relatedly, in line with IP theory which fundamentally claims some necessary knowledge should be possessed for effective international activities (Welch et al. 2016; Sapienza et al. 2006), we take a more objective stance which assumes 
opportunities are 'out there.' However, in entrepreneurship literature, another prevalent stance (i.e., creation perspective) denies this assumption and maintains entrepreneurial opportunities can also be created (Alvarez and Barney 2007). Although a thorough discussion of these two contrasting views is beyond the scope of this study, we should admit that the topic of international opportunity pursuit in a digitally enabled world can possibly be better understood if this creation perspective would be addressed.

A further investigation of DTs as 'driving force' and DTs as 'disrupting force' is another area which can be explored. For instance, scholars can continue to investigate and identify other factors regarding how these emerging technologies facilitate knowledge accumulation and change the relative importance of experiential knowledge. Moreover, as we discuss these two perspectives separately, some efforts can be taken to examine whether and how some specific categories of DTs can play both roles at the same time.

In addition, while our primary focus in this chapter is to explore how to acquire knowledge and how knowledge matters for opportunity pursuit in a digitally enabled world, knowledge perspective studies have also underlined the importance of knowledge application (Alavi and Leidner 2001; Grant 1996). The ability of knowledge application by nature varies across the firms (Wu et al. 2019), and therefore should be considered as the boundary condition for the conceptual framework proposed here.

\subsection{Conclusion}

There is no doubt that digitalization has challenged the traditional pattern of doing business including opportunity pursuit in foreign markets. Past studies have offered many valuable insights with regard to international opportunity creation and capture in a digitally enabled world, but they are generally scattered and fragmented. Drawing on entrepreneurship literature and IB literature, this study develops a conceptual framework and adds knowledge to the literature by categorizing the role of DTs into two perspectives, that is, DTs as 'driving force' and DTs as 'disrupting force.' We hope this framework is instrumental and could potentially serve as a guide for future researches.

Acknowledgements The authors wish to thank Mat Hughes, Mariusz Soltanifar and Lutz Göcke for their valuable feedback on the early version of the manuscript, and participants at the Colearning seminar for their comments. This work is supported by the National Natural Science Foundation of China (Grant No. 71572174, 71972166) and the National Social Science Foundation of China (Grant No. 17ZDA050). 


\section{References}

Ahlstrom, D., Bruton, G. D., \& Lui, S. S. (2000). Navigating China's changing economy: Strategies for private firms. Business Horizons, 43(1), 5-15.

Alarcón-del-Amo, M., Rialp-Criado, A., \& Rialp-Criado, J. (2018). Examining the impact of managerial involvement with social media on exporting firm performance. International Business Review, 27(2), 355-366.

Alavi, M., \& Leidner, D. E. (2001). Knowledge management and knowledge management systems: Conceptual foundations and research issues. MIS Quarterly, 25(1), 107-136.

Alcácer, J., Cantwell, J., \& Piscitello, L. (2016). Internationalization in the information age: A new era for places, firms, and international business networks? Journal of International Business Studies, 47(5), 499-512.

Alvarez, S. A., \& Barney, J. B. (2007). Discovery and creation: Alternative theories of entrepreneurial action. Strategic Entrepreneurship Journal, 1(1-2), 11-26.

Alvarez, S. A., \& Barney, J. B. (2014). Entrepreneurial opportunities and poverty alleviation. Entrepreneurship Theory and Practice, 38(1), 159-184.

Amit, R., \& Han, X. (2017). Value creation through novel resource configurations in a digitally enabled world. Strategic Entrepreneurship Journal, 11(3), 228-242.

Autio, E. (2017). Strategic entrepreneurial internationalization: A normative framework. Strategic Entrepreneurship Journal, 11(3), 211-227.

Autio, E., Nambisan, S., Thomas, L. D., \& Wright, M. (2018). Digital affordances, spatial affordances, and the genesis of entrepreneurial ecosystems. Strategic Entrepreneurship Journal, 12(1), 72-95.

Autio, E., Sapienza, H. J., \& Almeida, J. G. (2000). Effects of age at entry, knowledge intensity, and imitability on international growth. Academy of Management Journal, 43(5), 909-924.

Blomstermo, A., Eriksson, K., Lindstrand, A., \& Sharma, D. D. (2004). The perceived usefulness of network experiential knowledge in the internationalizing firm. Journal of International Management, 10(3), 355-373.

Chandra, Y., \& Coviello, N. (2010). Broadening the concept of international entrepreneurship: 'Consumers as international entrepreneurs'. Journal of World Business, 45(3), 228-236.

Chen, L., Shaheer, N., Yi, J., \& Li, S. (2019). The international penetration of ibusiness firms: Network effects, liabilities of outsidership and country clout. Journal of International Business Studies, 50(2), 172-192.

Coviello, N., Kano, L., \& Liesch, P. W. (2017). Adapting the Uppsala model to a modern world: Macro-context and microfoundations. Journal of International Business Studies, 48(9), 11511164.

Davidsson, P. (2015). Entrepreneurial opportunities and the entrepreneurship nexus: A re-conceptualization. Journal of Business Venturing, 30(5), 674-695.

Eckhardt, J. T., \& Shane, S. A. (2003). Opportunities and entrepreneurship. Journal of Management, 29(3), 333-349.

Eduardsen, J. S., \& Ivang, R. (2016). Internet-enabled internationalisation: A review of the empirical literature and a research agenda. International Journal of Business Environment, 8 (2), 152-175.

Eriksson, K., Johanson, J., Majkgård, A., \& Sharma, D. D. (1997). Experiential knowledge and cost in the internationalization process. Journal of International Business Studies, 28(2), 337 360.

Fischer, E., \& Reuber, A. R. (2014). Online entrepreneurial communication: Mitigating uncertainty and increasing differentiation via Twitter. Journal of Business Venturing, 29(4), 565-583.

Fletcher, M., \& Harris, S. (2012). Knowledge acquisition for the internationalization of the smaller firm: Content and sources. International Business Review, 21(4), 631-647. 
Foss, N. J., Lyngsie, J., \& Zahra, S. A. (2013). The role of external knowledge sources and organizational design in the process of opportunity exploitation. Strategic Management Journal, 34(12), 1453-1471.

Gabrielsson, M., \& Gabrielsson, P. (2011). Internet-based sales channel strategies of born global firms. International Business Review, 20(1), 88-99.

Glavas, C., Mathews, S., \& Russell-Bennett, R. (2019). Knowledge acquisition via internet-enabled platforms: Examining incrementally and non-incrementally internationalizing SMEs. International Marketing Review, 36(1), 74-107.

Grant, R. M. (1996). Toward a knowledge-based theory of the firm. Strategic Management Journal, 17(S2), 109-122.

Gregory, G., Karavdic, M., \& Zou, S. (2007). The effects of e-commerce drivers on export marketing strategy. Journal of International Marketing, 15(2), 30-57.

Hashai, N. (2011). Sequencing the expansion of geographic scope and foreign operations by "born global" firms. Journal of International Business Studies, 42(8), 995-1015.

Hilmersson, M., \& Jansson, H. (2012). Reducing uncertainty in the emerging market entry process: On the relationship among international experiential knowledge, institutional distance, and uncertainty. Journal of International Marketing, 20(4), 96-110.

Hmieleski, K. M., \& Baron, R. A. (2008). Regulatory focus and new venture performance: A study of entrepreneurial opportunity exploitation under conditions of risk versus uncertainty. Strategic Entrepreneurship Journal, 2(4), 285-299.

Johanson, J., \& Vahlne, J. E. (1977). The internationalization process of the firm-A model of knowledge development and increasing foreign market commitments. Journal of International Business Studies, 8(1), 23-32.

Johanson, J., \& Vahlne, J. E. (2009). The Uppsala internationalization process model revisited: From liability of foreignness to liability of outsidership. Journal of International Business Studies, 40(9), 1411-1431.

Kirzner, I. M. (1997). Entrepreneurial discovery and the competitive market process: An Austrian approach. Journal of Economic Literature, 35(1), 60-85.

Knight, G. A., \& Liesch, P. W. (2016). Internationalization: From incremental to born global. Journal of World Business, 51(1), 93-102.

Lew, Y. K., Sinkovics, R. R., Yamin, M., \& Khan, Z. (2016). Trans-specialization understanding in international technology alliances: The influence of cultural distance. Journal of International Business Studies, 47(5), 577-594.

Lopez, L. E., Kundu, S. K., \& Ciravegna, L. (2009). Born global or born regional? Evidence from an exploratory study in the Costa Rican software industry. Journal of International Business Studies, 40(7), 1228-1238.

Mainela, T., Puhakka, V., \& Servais, P. (2014). The concept of international opportunity in international entrepreneurship: A review and a research agenda. International Journal of Management Reviews, 16(1), 105-129.

Mathews, S., Bianchi, C., Perks, K. J., Healy, M., \& Wickramasekera, R. (2016). Internet marketing capabilities and international market growth. International Business Review, 25(4), 820-830.

McDougall, P. P., \& Oviatt, B. M. (2000). International entrepreneurship: The intersection of two research paths. Academy of Management Journal, 43(5), 902-906.

Moen, Ø., Madsen, T. K., \& Aspelund, A. (2008). The importance of the internet in international business-to-business markets. International Marketing Review, 25(5), 487-503.

Nambisan, S. (2017). Digital entrepreneurship: Toward a digital technology perspective of entrepreneurship. Entrepreneurship Theory and Practice, 41(6), 1029-1055.

Okazaki, S., \& Taylor, C. R. (2013). Social media and international advertising: Theoretical challenges and future directions. International Marketing Review, 30(1), 56-71.

Oviatt, B. M., \& McDougall, P. P. (2005). Defining international entrepreneurship and modeling the speed of internationalization. Entrepreneurship Theory and Practice, 29(5), 537-553. 
Paul, J., \& Gupta, P. (2014). Process and intensity of internationalization of IT firms-Evidence from India. International Business Review, 23(3), 594-603.

Pergelova, A., Manolova, T., Simeonova-Ganeva, R., \& Yordanova, D. (2019). Democratizing entrepreneurship? Digital technologies and the internationalization of female-led SMEs. Journal of Small Business Management, 57(1), 14-39.

Prasad, V. K., Ramamurthy, K., \& Naidu, G. M. (2001). The influence of internet-marketing integration on marketing competencies and export performance. Journal of International Marketing, 9(4), 82-110.

Reuber, A. R., \& Fischer, E. (2011). International entrepreneurship in internet-enabled markets. Journal of Business Venturing, 26(6), 660-679.

Reuber, A. R., Knight, G. A., Liesch, P. W., \& Zhou, L. (2018). International entrepreneurship: The pursuit of entrepreneurial opportunities across national borders. Journal of International Business Studies, 49(4), 395-406.

Sapienza, H. J., Autio, E., George, G., \& Zahra, S. A. (2006). A capabilities perspective on the effects of early internationalization on firm survival and growth. Academy of Management Review, 31(4), 914-933.

Shaheer, N. A., \& Li, S. (2020). The CAGE around cyberspace? How digital innovations internationalize in a virtual world. Journal of Business Venturing, 35(1), 105892.

Shane, S. (2000). Prior knowledge and the discovery of entrepreneurial opportunities. Organization Science, 11(4), 448-469.

Shane, S., \& Venkataraman, S. (2000). The promise of entrepreneurship as a field of research. Academy of Management Review, 25(1), 217-226.

Sigfusson, T., \& Chetty, S. (2013). Building international entrepreneurial virtual networks in cyberspace. Journal of World Business, 48(2), 260-270.

Stinchcombe, A. L. (1965). Social structure and organizations. In J. G. March (Ed.), Handbook of organizations (pp. 142-193). Chicago, IL: Rand McNally.

Tencent. (2019). Tencent announces 2019 first quarter results. https://www.tencent.com/en-us/ articles/8003551557911908.pdf. Retrieved July 15, 2019.

Tilson, D., Lyytinen, K., \& Sørensen, C. (2010). Digital infrastructures: The missing IS research agenda. Information Systems Research, 21(4), 748-759.

Tolstoy, D., Jonsson, A., \& Sharma, D. D. (2016). The influence of a retail firm's geographic scope of operations on its international online sales. International Journal of Electronic Commerce, 20(3), 293-318.

Welch, C., Nummela, N., \& Liesch, P. (2016). The internationalization process model revisited: An agenda for future research. Management International Review, 56(6), 783-804.

Wu, A., Song, D., \& Yang, Y. (2019). Untangling the effects of entrepreneurial opportunity on the performance of peasant entrepreneurship: The moderating roles of entrepreneurial effort and regional poverty level. Entrepreneurship and Regional Development. https://doi.org/10.1080/ 08985626.2019.1640479.

Yamin, M., \& Sinkovics, R. R. (2006). Online internationalisation, psychic distance reduction and the virtuality trap. International Business Review, 15(4), 339-360.

Yoo, Y., Boland, R. J., Jr., Lyytinen, K., \& Majchrzak, A. (2012). Organizing for innovation in the digitized world. Organization Science, 23(5), 1398-1408.

Young, S. L., Welter, C., \& Conger, M. (2018). Stability vs. flexibility: The effect of regulatory institutions on opportunity type. Journal of International Business Studies, 49(4), 407-441.

Zaheer, S. (1995). Overcoming the liability of foreignness. Academy of Management Journal, 38 (2), 341-363. 
Zahra, S. A. (2005). A theory of international new ventures: A decade of research. Journal of International Business Studies, 36(1), 20-28.

Zhou, L. (2007). The effects of entrepreneurial proclivity and foreign market knowledge on early internationalization. Journal of World Business, 42(3), 281-293.

Open Access This chapter is licensed under the terms of the Creative Commons Attribution 4.0 International License (http://creativecommons.org/licenses/by/4.0/), which permits use, sharing, adaptation, distribution and reproduction in any medium or format, as long as you give appropriate credit to the original author(s) and the source, provide a link to the Creative Commons license and indicate if changes were made.

The images or other third party material in this chapter are included in the chapter's Creative Commons license, unless indicated otherwise in a credit line to the material. If material is not included in the chapter's Creative Commons license and your intended use is not permitted by statutory regulation or exceeds the permitted use, you will need to obtain permission directly from the copyright holder.

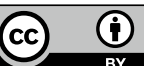

